\title{
China in the Post-World War II International Legal System \\ Sheng Hongsheng
}

\begin{abstract}
Dramatic changes have taken place in the international legal system since the end of World War II, such as the expanding arenas for application of international law, the emergence of a series of new legal institutions, and the parallel extension of both rights and obligations of states. In recent years, new developments have been arising in the international legal system, manifested by three important sets of transition, that is, from a "sovereign priority" to a "human rights priority"; from "consentorientation" to "coercion-orientation"; and from "integrity" to "fragmentation." The rise of China and the evolution of international law are closely related: while China's ascent has been achieved within the parameters of the international legal system, a more prosperous and stronger China will certainly influence the future trajectory of the evolving system. China should and can be a positive force in constructing a contemporary international legal order through promoting domestic justice and international rule of law. In this process, China needs to take a more proactive role and
\end{abstract}

Sheng Hongsheng is Professor of International Law at the Shanghai University of Political Science and Law, and a Research Fellow at the China Institute for SCO International Exchange and Judicial Cooperation.

The author is grateful for the support provided by the Program for Innovative Research Team, Shanghai University of Political Science and Law, in the writing of this paper.

(C) 2015 World Century Publishing Corporation and Shanghai Institutes for International Studies China Quarterly of International Strategic Studies, Vol. 1, No. 2, 205-222

DOI: $10.1142 / S 2377740015500104$ 
evolve from being a recipient to a rule-maker, in order to modify the outdated principles and rules in international law.

Keywords: International legal system; rise of China; international legal order; transformation.

\begin{abstract}
The seventy years after World War II have witnessed tremendous progress in the evolution of the international legal system. It is both necessary and conducive, for both theoretical and practical purposes, to trace the general trends as well as the major elements of the systemic transition, so as to discover the dynamics of interaction between a rising China and the evolving international legal system.
\end{abstract}

\title{
Post-World War II International Law and Beyond
}

A series of important international conferences convened in the concluding years of World War II put up a post-war order in political, economic, military, and legal terms. ${ }^{1}$ As a component of the post-war international regime, the international legal system has undergone great changes, exerting great impact on the development of the international order.

Above all, both the subjects and objects of international law have increased. Especially in recent years, international organizations, non-governmental organizations, and even individuals have been playing more and more significant roles in international politics. The subjects of international law have never been so pluralistic and so difficult to define, particularly with the rise of non-state actors like Al-Qaeda and the Islamic State of Iraq and al-Sham (ISIS). Accordingly, the objects of international law have also expanded gradually, from acts of states and activities in the traditional domains of international law to those in the outer space, the seabed and ocean floor, polar areas, and even cyberspace. When Ebola broke out on a large scale in West Africa in December 2013, the United Nations Security Council convened consecutive meetings to discuss critical threats to

\footnotetext{
${ }^{1}$ For a detailed description of such conferences and their achievements in establishing the post-World War II international legal order, see Gong Xiangqian, “The United Nations and Development of International Legal Order," Politics and Law, No. 1 (January/February 2004), and Antje Weiner et al., "Global Constitutionalism: Human Rights, Democracy and the Rule of Law,"Global Constitutionalism, Vol. 1, No. 1 (March 2012), p. 1.
} 
international peace and security such as epidemics and feasible countermeasures to be taken by the international community. Indeed, it was unprecedented for the Security Council (with a chief mandate to uphold international peace and security) to organize specialized meetings on issues related to diseases, hygiene, and public health.

The post-World

War II international

legal order has

undergone major

changes, focusing

more on human

rights and human

security.

Next, new institutions of international law have come into being one after another, and both the rights and obligations of states have expanded on a parallel level. In contemporary international law, there are many new sub-areas such as international administrative law, international tourist law, nuclear law, polar law and so on, in comparison to fewer than a dozen institutions of traditional international law several decades ago. Over the past few years, the hazards of climate change have triggered the opening of new shipping routes in the Arctic region and a number of non-Arctic states have claimed rights to the region based on different arguments. The boundary between states' jurisdiction over internal and external affairs has been blurred and issues previously within domestic jurisdiction have increasingly expanded to a point that require international jurisdiction, such as human rights protection, health issues, environmental protection, anti-terrorism, and crackdown on trans-boundary crimes. It is now more difficult for states to use "internal affairs" as justification for rejecting international jurisdiction. In other words, the sphere of "state reservation" has diminished dramatically. ${ }^{2}$

Furthermore, the international human rights law and international humanitarian law have imposed restrictions on the use of violence, and no matter what new means and methods of warfare come into being, the "principle of humanity" always prevails. Even if new military technologies are developed to influence the means and methods of warfare, such means

${ }^{2}$ Liang Xi, ed., International Law (Wuhan: Wuhan University Press, 2000), p. 31. 
and methods remain subject to "the Martens Clause." ${ }^{3}$ Some scholars point out that "the reason why the Martens Clause is so critical is just because it stresses the importance of customary rules regulating armed conflict via customary law." ${ }^{4}$ Some other Western scholars hold that

even the most perfect legal rules cannot exhaust all of the possibilities. The more detailed circumstances legal rules stipulate, the more risks of leakage there will be. So in this case, if no concrete provisions for the Geneva Conventions of 1949 can be invoked, the Martens Clause will function as a 'safety valve'. ${ }^{5}$

In the meantime, the nature of "weak law" in international law has been changed to some extent through the enhancement of sanctions in international law and the resurrection and rapid development of international criminal justice. ${ }^{6}$

With regard to the above changes and based on the emerging theories and norms in international law in recent years, it is reasonable to predict the medium- and long-term trends in the international legal system.

Firstly, issues covered by international law will keep on proliferating to include affairs not only in "high politics" but also in "low politics." In

${ }^{3}$ In the Preamble of Laws and Customs of War on Land (Hague IV), it reads "Until a more complete code of the laws of war has been issued, the High Contracting Parties deem it expedient to declare that, in cases not included in the Regulations adopted by them, the inhabitants and the belligerents remain under the protection and the rule of the principles of the law of nations, as they result from the usages established among civilized peoples, from the laws of humanity, and the dictates of the public conscience." This is called the Martens Clause by legal scholars.

${ }^{4}$ Rupert Ticehurst, "The Martens Clause and the Laws of Armed Conflict,"International Review of the Red Cross, No. 317 (April 1997), pp. 125-134.

${ }^{5}$ Stanislav E. Nahlik, "A Brief Outline of International Humanitarian Law," International Review of the Red Cross (July/August 1984), pp. 36-37.

${ }^{6}$ Under the terms of a resolution unanimously adopted by the United Nations Security Council on February 24, 2015, members decided to extend the mandate of the group of four experts on Yemen, which was established to oversee sanction measures employed against individuals and entities designated as threatening peace, security or stability in the country. See United Nations News Center, "Security Council Renews Yemen Sanctions Panel for 13 Months to Promote Political Transition," February 24, 2015, http://www.un.org/apps/news/ story.asp?NewsID=50166\#.VRYHddLLp1A. 
fact, international law is shifting its past focus on "international peace and security" to the current focus on "security and socio-economic development."

Secondly, the value basis for international law will undergo significant changes, namely, from a "sovereignty priority" to a "human rights priority." Under the guidance of "human rights supremacy," international criminal law uses its sharp swords to pierce through the "last layer of armor" that is state sovereignty, and by resorting to universal jurisdiction and circumvention of judicial independence, diplomatic immunities and privileges, it attempts to impose obligations on individuals (including government officials entitled to privileges and immunities), so as to subdue the so-called "impunity" and be able to punish grave violations of human rights. At the same time, it is controversial that the Rome Statute applies to non-contracting states and this breaches an important principle in the law of treaty in international law pacta tertiis nec nocent nec prosunt (Treaties do not impose any obligations, nor confer any rights, on third States).

Thirdly, international law will transform from being "consent-based" to being "coercion-based," which stresses "norms" instead of "wills." Take United Nations peacekeeping operations as an example. Their traditional mandate is to keep peace, but "peace-enforcement" emerged promptly as a term in the 1990s when the United Nations peacekeeping forces simultaneously resorted to force to suppress one of the warring parties or to enforce ceasefire by coercion. It was permissible for United Nations peacekeepers to use minimum force for self-defense only. However, in a guideline for the United Nations peacekeeping operations issued by the Peacekeeping Department of the United Nations in 2008, no use of force unless for self-defense became "no use of force for self-defense and implementing mandate." ${ }^{7}$ Besides, the well-known Brahimi Report ${ }^{8}$ has made a consequential change by stipulating that in United Nations peacekeeping operations, "Impartiality does not necessarily mean neutrality." ${ }^{9}$ All the phenomena mentioned above imply that there is a

${ }^{7}$ Qi Sanping et al., eds., International Humanitarian Law in Peace Operations (Beijing: Military Science Press, 2012), p. 225.

${ }^{8}$ Report of the Panel on United Nations Peacekeeping (A/55/305-S/2000/809).

${ }^{9}$ See Sheng Hongsheng, The United Nations Peace-Keeping Operations: Legal Aspects (Beijing: Current Affairs Press, 2006), p. 146. 
tendency for international law to transform from a "consent-based" to a "coercion-based" approach.

Fourthly, more and more conflicts will take place between different departments of international law, reflecting a shift from "integrity" to "fragmentation" of the international law regime. This is embodied prominently by clashes between several pair issues, for instance, individual culpability and diplomatic privileges, responsibility to protect and nonintervention in domestic affairs, and international jurisdiction and internal jurisdiction, just to name a few.

Finally, some legal powers attempted to make their municipal law "spill over" into international law, ${ }^{10}$ and the transition process from "international morality" to "international law" has been accelerated. Moreover, even some moral norms at the personal level are being promoted to law as an outcome of mainstream values held by Western powers.

\section{China's Status in the International Legal Order}

Although some tokens of "international law" can be found in ancient China, ${ }^{11}$ its concepts of "state," "international" and even "law" do not match the equivalent notions we use today. According to Liang $\mathrm{Xi}$, "International law was imported to China from the West only after the Opium War in $1840 .{ }^{\prime 12}$ It was argued by some other scholars, however, that China had the first acquaintance with modern international law as early as in the mid-seventeenth century. ${ }^{13}$ Nevertheless, in over a hundred years after that, Western powers waged consecutive wars against China with powerful weapons and warships, imposing a series of unequal treaties, carving up Chinese territory and extracting large sums of war indemnities. International law was by no means a tool to safeguard China's state interests.

${ }^{10}$ For example, Belgium enacted the Law of Universal Jurisdiction in 1993 which aroused international controversy.

${ }^{11}$ See Chen Guyuan, Tracing International Law in China (Taiwan: Commercial Press, 1973); Liu Daren and Yuan Guoqin, Developments in the History of International Law (Beijing: Fangzheng Press, 2007); and Sun Yurong, A Study in International Law in Ancient China (Beijing: China University of Political Science and Law Press, 1999).

${ }^{12}$ See Liang Xi, ed., International Law (Wuhan: Wuhan University Press, 2000), p. 36.

${ }^{13}$ See Yang Zewei, An Outline of History of International Law (Beijing: Higher Education Press, 2011), p. 336. 
On the contrary, modern international law left huge liabilities for China, such as spheres of influence, extra-territoriality, and concessions. As late as 1943, close to the end of World War II, Western powers like the United States still often invoked "extra-territoriality" in China. Thus, China was by and large a subservient victim of international law for over a century.

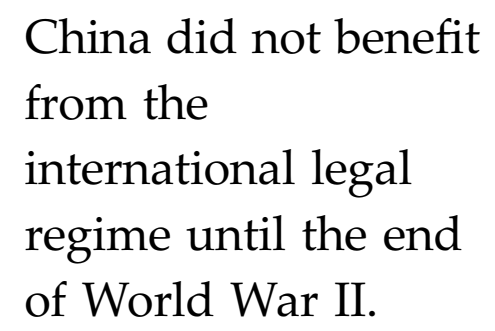

Only after the end of World War II did China, as a member of the victorious allied forces, begin to enjoy the benefits of a stable international legal order. First of all, China was able to claim its world power status as a founding member of the United Nations and one of the five permanent members of the UN Security Council. It made tremendous sacrifice and irreplaceable contributions to the war against Fascism as one of the major forces on World War II battlefields. Toward the end of the war, China took part in almost every major international conference. Chinese delegates signed the Charter of the United Nations cementing China's founding member status in San Francisco on October 24, 1945, and China managed to assume permanent membership in the United Nations Security Council, armed with veto power. This fact, for the first time in history and by law, secured China's position as a world power.

Secondly, China began to exercise significant voting and decisionmaking power as a permanent member of the United Nations Security Council and many other crucial posts in other international organizations. In October 1971, the People's Republic of China formally assumed its permanent seat and became entitled to all legal rights in the United Nations. Apart from being a permanent member in the United Nations Security Council, China held more and more leading positions in the United Nations Trusteeship Council, International Court of Justice, World Bank, International Monetary Fund, and other organizations, all of which made it possible for China to exercise its voting and decision-making power for critical issues in the international arena.

Lastly, a guarantee mechanism for prevention of war was provided by the post-war international legal system in general and the collective security regime under the United Nations Charter in particular, which created a favorable external environment for China's social and economic development. On February 23, 2015, Chinese Foreign Minister Wang Yi chaired a UN 
ministerial-level open debate on the 70th anniversary marking the victory of the war against Fascism and the founding of the United Nations, to reflect on history and reaffirm the commitment to the principles of the UN Charter. He pointed out that "The Security Council needs to take more precautionary measures to forestall conflict and act in a timely manner to stop warfare." ${ }^{14}$ As an outcome of the anti-Fascism war, together with other states, the victorious Allied States established a political and legal order for the post-war world, in which the most prominent institutional arrangements included restriction of sovereignty for Japan and Germany, ${ }_{1}^{15}$ such as the occupation of both countries, imposition of peaceful constitutions, ${ }^{16}$ the limitation of regular armed forces, and the renunciation of the right to belligerency.

\section{China's Contribution to Modern International Law}

Over the past seven decades, relations between China and the international legal system have undergone a zigzag process, with contradictions and conflicts coupled with coordination and mutual accommodation. In terms of theoretical exploration and law enforcement, China has exerted great impact upon the formation and evolution of the post-World War II international legal system.

Together with India and Myanmar, China put forward "the Five Principles of Peaceful Co-Existence," a significant contribution to the system of fundamental principles of contemporary international law. ${ }^{17}$ In late 1954, Premier Zhou Enlai was invited to visit India and Myanmar, and "the

${ }^{14}$ United Nations News Center, “Chinese Foreign Minister Wang Yi Chairs Ministerial Open Debate in the UN Security Council Stresses Realistic Importance of the United Nations Charter," February 23, 2015, http://www.un.org/chinese/News/story.asp?newsID=23502.

${ }^{15}$ In accordance with Article 107 of the United Nations, nothing in the present Charter shall invalidate or preclude action, in relation to any state which during the Second World War has been an enemy of any signatory to the present Charter, taken or authorized as a result of that war by the Governments having responsibility for such action.

${ }^{16}$ Article 26, Paragraph 1, Basic Law of Federal Republic of Germany, and Article 9, Constitution of State of Japan.

17 "The Five Principles of Peaceful Co-Existence" are mutual respect for each other's territorial integrity and sovereignty, mutual non-aggression, mutual non-interference in each other's internal affairs, equality and cooperation for mutual benefit, and peaceful co-existence. 
Five Principles of Co-Existence" were publicized in the Joint Communiques of China, India, and Myanmar. Essentially, the Five Principles coincided with "the Seven Principles of the United Nations Charter," and they were basic principles of international law initiated for the first time by states other than Western powers, complementing and improving the system of contemporary international law.

Meanwhile, China also began to provide increasing international public goods by participating in UN peacekeeping operations. Chinese participation should be regarded as constituting military diplomacy in China's overall diplomacy. It was an effective approach for China to provide public goods in high politics (for international peace and humanitarian protection) to the international community and a way to build up China's international image and win it international esteem for being a responsible power through creative involvement. ${ }^{18}$

China has always tried to uphold international justice and has consistently observed the fundamental principles of contemporary international law and basic principles of international relations as well. China has always emphasized that the principles of state sovereignty and noninterference should be adhered to strictly, and in the past, China has more often than not cast veto in the Security Council on several occasions to prevent some states from abusing UN mandates by interfering in the domestic affairs of other states. For instance, from February to July 2011, in voting procedures regarding the Syrian crisis, China, together with Russia, exercised their veto votes three consecutive times in the Security Council of the United Nations. For crucial issues like the Iranian and DPRK nuclear issues, China argues that international disputes should be settled by peaceful means, instead of resorting to the use or threat of force.

Besides, China is contributing to international justice by supporting African states' efforts in avoiding the negative effects of international criminal justice prosecution. Up till now, all of the nine "situations" ${ }^{19}$ under

${ }^{18}$ See Wang Yizhou, Creative Involvement: Emergency of a Global Role for China (Beijing: Peking University Press, 2013).

${ }^{19}$ Pursuant to the Rome Statute, the Prosecutor can initiate an investigation on the basis of a referral from any State Party or from the United Nations Security Council. In addition, the Prosecutor can initiate investigations propriomotu on the basis of information on crimes within the jurisdiction of the Court received from individuals or organizations ("communications"). 
review by the International Criminal Court have come from African states without exception, these have aroused harsh controversy and led to severe divisions within the international community. ${ }^{20}$

Recalling the four centuries of international law since the Peace of Westphalia in 1648, it is not difficult to find that each great change in international law - from the principle of sovereign equality to the renunciation of extra-territoriality, from the establishment of the basic principles to the alteration of concrete rules, etc. - has been related to changes in the balance of international economic and political power. With its growing economic size and increasing share of the world's total GDP, China is demanding greater discourse power commensurate with its rising national power. In general, China's interaction with the international legal system during the past decades demonstrated the following three dimensions:

The first is China's proactive involvement in international organizations of an economic nature. It sought to restore its original contracting party status of the General Agreement on Tariffs and Trade (or GATT, the WTO's precursor) as early as 1986, and made significant adjustment and adaptation to win accession to the WTO, so that its own economy could be connected to the global market, for economic exchanges are less affected by ideological and political factors.

The second dimension is China's diligent reservation over premature norms that have emerged in recent years. There is notable disagreement and considerable conflict over a number of international norms - the responsibility to protect, for one example - between China and some Western powers. ${ }^{21}$ In the past years, affected by the idea of international rule of law and global governance, the responsibility to protect has gained

${ }^{20}$ Ministry of Foreign Affairs of China, "UN Security Council Rotary Chairperson Chinese UN Ambassador Liu Jieyi Presides Security Council Meetings in November," November 4, 2013, http://www.fmprc.gov.cn/mfa_chn/wjdt_611265/zwbd_611281/t1095809. shtml.

${ }^{21}$ See Huang Yao, "The Doctrine of the Responsibility to Protect from the Perspective of the Law on the Use of Force," Chinese Journal of Law, No. 3 (May/June2012). 
instant currency. It is argued by some scholars that when governments are unable to protect their people, "timely and decisive" acts could be taken by the international society as a whole to take collective responsibility to protect people concerned from mass atrocities. The issue also attracts attention from Chinese scholars, but it is still arguable whether "to give protection" constitutes a right, an obligation or even a responsibility. ${ }^{22}$ However, the situation in Libya in 2011 changed the course of such debate. All of a sudden, and without preparation, Libya served as a testing ground for the exercise of a "responsibility to protect" and further judicial intervention by Western powers. ${ }^{23}$ As a matter of fact, the notion of the responsibility to protect has not been accepted broadly by the international society, and it is essentially a variation of "humanitarian intervention." Therefore, some Chinese academics argue that it "bears very thick moral color" to prioritize protection of individuals over the state sovereignty. ${ }^{24} \mathrm{In}$ the field of international criminal law, Chinese delegates cast an "against vote" when the Rome Statute was adopted in 1998, because China held that jurisdiction by the International Criminal Court by the Statute almost established universal jurisdiction, ${ }^{25}$ and this would be detrimental to judicial sovereignty of a third party, affect the judicial procedure of a state against its will, and cause long-term tensions and chaos in international relations.

The third dimension is China's affirmative and positive position and involvement in international peacekeeping operations in general and peacekeeping operations by the United Nations in particular. Over the past decades, China has shifted from staying out of UN peacekeeping operations to cautious involvement, and then to active participation and coordination with the rest of the international society. Especially with the end of the Cold War, China has become increasingly active in taking part in United Nations

${ }^{22}$ See Cai Congyan, "The Nature of Enforcement of R2P by the United Nations: From Political Responsibility to Legal Obligation," Jurists, No. 4 (June/July, 2011).

${ }^{23}$ See Song Jie, “Judicial Intervention in International Relations: An Intervention Era Is Coming," World Economics and Politics, No. 7 (July 2011).

${ }^{24}$ See Liu Bo, "New Developments in Western Doctrine of Humanitarian Intervention," China Science Post, September 9, 2013, p. 7.

${ }^{25}$ According to some British scholars, there are no general rules to authorize states to punish foreign nationals who commit crimes against humanity, just as they are entitled to punish piracy. See Robert Jennings and Arthur Watts, eds., Oppenheim's International Law (London: Longman Group UK Limited and Mrs. Tomoko Hudson, 1992), pp. 363-364. 
peacekeeping operations by providing personnel, material, and funds. At present, China is the largest troop contributor to UN peacekeeping operations among the five permanent members of the UN Security Council. Participation in peacekeeping operations serves China's national interests, which includes but is not limited to establishing an image of a responsible great power, gaining support of war-torn states, expanding military exchanges with other states, and providing field-training opportunities for the Chinese military.

In short, China's contribution to world peace and international justice is showcased by its diplomacy with peculiarity, that is, empathetically facilitating evolution by inherent innovation rather than encouraging radical change or even revolution with external pressure.

\section{A Bigger Role for China to Play}

Like municipal law, the international legal system always lags behind reality. Similarly, China's aspirations can hardly be reflected immediately or fully in the transformation of the international legal regime either. At present, China is striving to enhance its voting power by proposing new rules in international law, in order to play a more proactive and constructive role in the creation of new international rules and norms. Toward this goal, China is facing many favorable conditions as well as daunting challenges.

On the positive list, the first is the well-established political and legal systems of the world today. As the world order developed since the end of World War II has played an important role in preventing wars in the last seventy years, it is preferable for China to maintain the current United Nations political and legal systems in general and "Unanimity of Powers" and non-proliferation of nuclear weapons in particular.

The second positive factor is that China has gained more and more voting power in international justice with an increasing number of Chinese judges, committee members and arbitrators in international organizations. ${ }^{26}$ In 2012, all the Chinese candidates were elected into the five major

${ }^{26}$ See Sheng Hongsheng, “Growing Legal Influences: China gets Increasingly Involved in International Law Making and Enforcement," Beijing Review, Vol. 54, No. 40 (October 6, 2011). 
judicial organs of the United Nations including the International Court of Justice and the International Law Commission. A new legal culture and new legal ideas are thus being introduced into the process for the settlement of international disputes by international judicial institutions, which will greatly enhance multi-polarity and inclusiveness of international justice. Besides, China also enjoys increasing voting power in international organizations of an economic nature. Since joining the WTO in 2001, China has not only conducted international economic activities based on WTO principles, but also tried to resolve legal disputes with other members according to such principles. From 2004 to date, 11 Chinese scholars have been designated by the WTO Appellate Body as judges, legal experts or lawyers.

The third positive factor is that China has already achieved much progress in the joint establishment of new international organizations. In 1997, the International Network for Bamboo and Rattan became the first international organization headquartered in China. China also played a leading role in the creation of the Shanghai Cooperation Organization (SCO), whose Secretariat is located in Beijing. As a new type of regional organization, the SCO does not target any third party, but aims to promote cooperation among its member states in fighting against terrorism, separatism and extremism, so as to maintain regional peace despite the many misinterpretations of the organization as an unlawful and anti-Western alliance. ${ }^{27}$ In a more recent example, many global and regional powers like the United Kingdom, France, Germany, Australia and South Korea expressed interest in joining the China-led Asian Infrastructure Investment Bank (AIIB) as founding members. By April 15, 2015, a total of 57 countries had joined the AIIB as founding members, including all major economies of the world apart from the U.S., Japan, and Canada. In fact, the initiative has gathered such momentum that many scholars are regarding it as a sign marking a substantial boost of China's international status.

The final positive factor is China's increasing soft power. While trying to enhance its comprehensive national strength, China has placed much

${ }^{27}$ Matthew Crosston, “The Pluto of International Organizations: Micro-Agendas, IO Theory, and Dismissing the Shanghai Cooperation Organization," Comparative Strategy, Vol. 32, No. 3 (July/August 2013), pp. 283-294; Stephen Aris and Aglaya Snetkov, "Global Alternatives, Regional Stability and Common Causes: The International Politics of the Shanghai Cooperation Organization and its relationship to the West," Eurasian Geography and Economics, Vol. 54, No. 2 (April, 2013), pp. 202-226. 
emphasis on soft power development as well, and put forward a series of new ideas to increase its moral appeal. ${ }^{28}$ Over the past few years, a series of new ideas have been proposed by the Chinese leadership, such as building a "Harmonious World," forging a "new type of major power relations," "win-win results of international relations," the "New Security Concept," the "One Belt and One Road Initiative" and the "Asian Dream." Besides, China has also initiated a series of bilateral and multilateral cooperation mechanisms like the Forum on China-Africa Cooperation and the Forum of China and the Community of Latin American and Caribbean States.

In the meantime, China is facing increasing challenges on its way to playing a bigger role in the international legal system as well. Now that Germany, Japan, India, Brazil and even South Africa are all eager to seek permanent memberships in the United Nations Security Council, the enlargement of the organization will inevitably weaken China's relative international standing and diminish its influence.

Besides, certain states or groups of states tend to interfere in China's domestic affairs by misinterpreting the principle of self-determination. Unsurprisingly, when the International Court of Justice released its Advisory Opinion regarding Kosovo's declaration of independence on July 22, 2010, claiming that it did not violate international law, both China and Russia held reservation for this critical issue under international law. ${ }^{29}$

Evolution of the international legal regime is challenging traditional leadership and jurisdiction of international law.

Another challenge China faces is that aggressive and invasive international criminal justice and universal jurisdiction is eroding state sovereignty and judicial independence. There seems to be a trend of international

${ }^{28}$ For soft power construction, see Zhang Chun, “On the Four-Step Strategy for China's Comprehensive Rising without Challenging the Existing International System," World Economics and Politics, No. 5 (May 2014).

${ }^{29}$ See Yu Mincai, "A Comment on ICJ Advisory Opinion Concerning Kosovo Independence," Studies in Law and Business, No. 6 (November/December 2010); He Zhipeng, "Judicial Dilemma in Power Politics: A Reflection on ICJ Advisory Opinion Concerning Kosovo Independence," Studies in Law and Business, No. 6 (November/December 2010). 
judicial intervention. After the end of the Cold War, international criminal law underwent resurrection and rapid development, ${ }^{30}$ and in no more than twenty years, seven international criminal institutions have been set up. As a result, many states and international organizations have begun to hold serious reservations or even objection to universal jurisdiction, ${ }^{31}$ aiming to prevent the International Criminal Court from becoming a political instrument to achieve the selfish interests of the states concerned. In terms of a definition for the crime of aggression, ${ }^{32}$ China insists that the issue is so important that the definition should be given by the United Nations Security Council instead of the International Criminal Court. In recent years, there are some cases relating to law suits against incumbent and retired Chinese leaders. As for the controversy, just as a Chinese delegate said at a United Nations conference,

As stated by the ICJ in the Arrest Warrant case, these officials can still be held criminally accountable without prejudice to the immunity from foreign criminal jurisdiction through measures such as prosecution by their own national courts, waiver of their immunity, prosecution at the termination of their tenure of office, and prosecution by an international criminal justice organ. Therefore, immunity is not necessary linked with impunity. ${ }^{33}$

The last challenge for China is the growing controversy over the principles in settling sovereign or security disputes. Today, on international maritime disputes, international judicial institutions are inclined to resort to the principle of "effectivités" (effective control) to adjudicate territorial

${ }^{30}$ Dirk van Zyl Smit, "Punishment and Human Rights in International Criminal Justice,"Human Rights Law Review, Vol. 2, No. 1 (January 2002).

${ }^{31}$ See "Princeton Principle on Universal Jurisdiction," Gao Mingxuan and Wang Xiumei, trans., Chinese Criminal Science, No. 3 (March 2002).

${ }^{32}$ See Yao Caifu, "The Development of the Conception of the Crime Aggression in International Law," Journal of University of International Relations, No. 4 (July/August 2011).

${ }^{33}$ Statement by Mr. Xu Hong, Chinese Delegate, Director-General of the Department of Treaty and Law of the Ministry of Foreign Affairs of China at the 69th Session of the UN General Assembly on Agenda Item 78 Report of the 66th Session of the International Law Commission (Part 2), http://www.fmprc.gov.cn/ce/ceun/eng/chinaandun/legalaffairs/sixthcommittee1/t1207044.htm. 
sovereignty over contested islands, which is detrimental to China and other countries that have remained less assertive over the past decades in territorial struggles with their neighbors. Take the case between Singapore and Malaysia, for example. The International Court of Justice ruled that Singapore has sovereignty over the Pedra Branca (White Rock), ${ }^{34}$ because Malaysia could not provide ample historical evidence to prove that it enjoyed sovereignty over the island in question after 1844, while Singapore has conducted long-time effective control over the rock concerned. ${ }^{35}$ This principle is not only evident in sovereignty disputes. On April 25, 2014, nine nuclear powers including China were sued by the Republic of the Marshall Islands on the charge of growing threat of nuclear proliferation, ${ }^{36}$ which poses a new challenge to the existing nuclear system dominated mainly by great powers.

Facing all the positive and negative factors for its increasing engagement with the international legal system, China not only needs to learn to play a more constructive role in the international arena, but also has to promote domestic rule of law as well, in order to match its municipal law with the development of international law.

There are two pathways to becoming a constructive power, gradual involvement and seeking benefit while evading damages. Given

China needs to match its municipal law with the evolving international law.

${ }^{34}$ International Court of Justice, Sovereignty over Pedra Branca/Pulau Batu Puteh, Middle Rocks and South Ledge (Malaysia/Singapore), http://www.icj-cij.org/docket/index. php?p1 $=3 \& \mathrm{p} 2=3 \& \operatorname{code}=$ masi\&case $=130 \& \mathrm{k}=2 \mathrm{~b} \& \mathrm{p} 3=0 ;$ http://www.icj-cij.org/docket/files/ 130/14492.pdf, and ICJ Judgment of May 23, 2008: Sovereignty over PedraBranca/PulauBatuPuteh, Middle Rocks and South Ledge (Malaysia/Singapore), Paragraph 196.

${ }^{35}$ ICJ Judgment of May 23, 2008, Sovereignty over Pedra Branca/Pulau Batu Puteh, Middle Rocks and South Ledge (Malaysia/Singapore), Paragraph 276; Huang Yao and Ling Jiaming, "On the Application of the Rule of Effective Control from the Perspective of International Judicial Decisions: Also on the Issues of Sovereignty over the Nansha (Spratly) Islands," Journal of Sun Yat-Sen University, Vol. 51, No. 4 (July/August 2011).

${ }^{36}$ Obligations concerning Negotiations relating to Cessation of the Nuclear Arms Race and to Nuclear Disarmament. 
the fact that the current international system is still largely dominated by Western powers, ${ }^{37}$ China will need to make full use of its advantages and resolve the above-mentioned negative factors in order to promote its own legal rights while enhancing the development of international law. It could be the best approach for China to promote developments in the international legal system by offering more and more public goods in the areas of both high and low politics, such as providing more foreign aid and increasing participation in United Nations peacekeeping operations. During the process, China should learn to take the lead in reforming the current international legal regime by initiating new norms and mechanisms to gradually replace the outdated principles and rules of international law.

\section{Conclusion}

Arguably, the rise of China can be considered as the most significant event in the evolution of the post-World War II international system. As a result of the changes in the international economic landscape, the balance of power in international politics and the decision-making power on major global affairs are also shifting, reflected in the declining dominance of Western powers in issues relating to development assistance and conflict prevention. The center of gravity of the global balance of power is shifting eastward. The relationship between China's rise and its interactions with the international legal system is becoming increasingly complicated, exerting farreaching and extensive influence on the future trajectory of the evolution of the international legal system.

In terms of governing international social relations, and compared with other norms, international law enjoys special and prominent advantages. The current international legal regime is in a period of rapid transition. It cannot adapt itself to the current international system unless broader reforms are taken by the international society.

It is beyond doubt that the post-World War II international legal system has deficiencies. It was built upon the old-time European system of international law, and it is therefore incomplete and under-representative, reflecting and serving the narrow interests of Western powers in particular.

\footnotetext{
${ }^{37}$ See Zhang Xiaoming, "A Rising China and Normative Changes in International Society," Foreign Affairs Review, No. 1 (January/February 2011).
} 
Similarly, China's interactions with the international legal system need to be reexamined as well. In the early days, due to ideological clashes, China framed international law in a negative light, and with few qualified international legal experts. It was difficult to formulate a sober assessment of the potential impacts of the principles and rules in international law. In an evolving international legal system and an emerging new international order, what China needs to do is project a positive image of a responsible major power. It must participate in international affairs as "an active insider" instead of "a detached observer," resolutely confronting issues that it has never faced before. On one hand, more efforts need to be taken to make sure that international law better represents and serve China's legitimate rights and interests as well as incorporate Chinese values, ideas about the rule of law, and legal philosophy. On the other hand, from a Chinese perspective and with a global vision, Chinese scholars and practitioners should contribute to the reform of the current international law, both in theory and in practice, so as to establish a more just and lasting international legal system. 